\title{
Description of Unplanned Actual Arm
}

National Cancer Institute

\section{Source}

National Cancer Institute. Description of Unplanned Actual Arm. NCI Thesaurus. Code C162128.

Description of the unplanned actual arm (of the clinical trial) in which the subject participated during the trial. 